The American Journal of Political Science Law and Criminology

(ISSN - 2693-0803)

VOLUME 04 ISSUE 01 Pages: 52-56

SJIF IMPACT FACTOR (2020: 5. 453) (2021: 5. 952)

OCLC - 1176274523 METADATA IF - 7.659

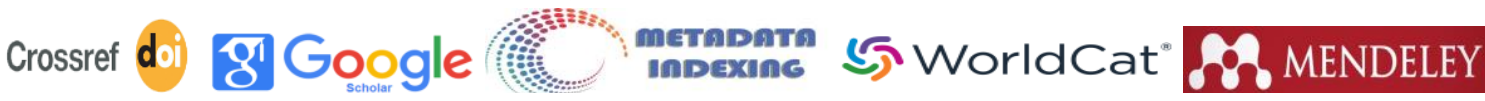

Research Article

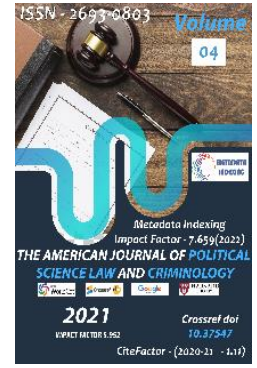

Journal Website: https://theamericanjou rnals.com/index.php/ta jpslc

Copyright: Original content from this work may be used under the terms of the creative commons attributes 4.0 licence.

\section{SOME LEGAL ISSUES OF STATE REGULATION OF INCLUSIVE EDUCATIONAL PROCESSES IN UZBEKISTAN}

\author{
Submission Date: January 09, 2022, Accepted Date: January 20, 2022, \\ Published Date: January 30, 2022 \\ Crossref doi: https://doi.org/10.37547/tajpslc/Volume04Issue01-09 \\ Ismoilov Bekjon Salikhovich \\ Independent researcher at Tashkent State University of Law, Uzbekistan
}

\title{
ABSTRACT
}

The article provides a detailed analysis of the legal aspects of including persons with disabilities through inclusive education. On the basis of reforms in the field of education, inclusive education is gradually developing in the Republic of Uzbekistan. The orientation towards this form of education at the state level serves to further expand the educational opportunities of students with disabilities. In addition, the article presents legal, analytical views on the fact that education is the most effective way of adapting young people with disabilities in a healthy society.

\section{KEYWORDS}

Inclusive education, state, students with disabilities.

\section{INTRODUCTION}

Today, measures to provide comprehensive support of people with disabilities in Uzbekistan gaining a specific social and legal meaning content in the state social protection policies. In the next stage of development of Uzbekistan, a number of significant work is being done to express the rights, freedoms and their legitimate interests of physical disabilities. "On the rights of persons with disabilities of the Republic of Uzbekistan". 15.10.2020. Law of the Republic of Uzbekistan "On ratification of the Convention on Persons with Disabilities (New York, 13.12.2006)" Ratification 07.06.2006) is the practical result of the 
The American Journal of Political Science Law and Criminology

(ISSN - 2693-0803)

VOLUME 04 ISSUE 01 Pages: 52-56

SJIF IMPACT FACTOR (2020: 5. 453) (2021: 5. 952)

OCLC - 1176274523 METADATA IF - 7.659

positive work carried out in this direction. In the national legislative system of Uzbekistan, the adoption of such special sectoral legal framework makes a great contribution to the adoption and implementation of such special wide legal framework. This issue is ensured by the right of people with disabilities and persons with disabilities to use the existing opportunities in society, travel, health, education, employment, rehabilitation, participation in the rehabilitation, political and social life. Based on the principle of "For human Qithor", large-scale reforms aimed at ensuring the inclusive development, ie equal rights and capabilities for all segments of the population play an important role. We are consistently working in this direction following the principle that people with disabilities are full members of society [1]. In this sense, people with disabilities of the Republic of Uzbekistan recognize that in all areas of their lives, equal rights with others [2]. If we think in important areas of integration of citizens with disabilities in the life of society, we can say without hesitation, the field of education is undoubtedly leader in this regard. We think that the existing people with the disabilities of inclusive education is crucial in adapting people to society without excessive obstacles. This is characterized by the following elements:

- The state control and control of the industry of education;

- Theization of the industry's sectoral legislation;

- Sustain-sustainable formulation of inclusive environment;

- Law guarantees legal guarantees for incolius education, with disabilities with disabilities and healthy students together.

The issue of education of students with disabilities is reflected in education, comprehensive and several laws and legislative acts. Article 20 of the Law of the
Republic of Uzbekistan This is the form of education aimed at providing equal opportunities for educational organizations for educational organizations, taking into account separate educational needs and diversity opportunities, given the diversity of individual educational needs. Inclusive education is organized in educational institutions for individuals or individuals with mental, sensor) or mental defects [3].

In the context of the gradual development of inclusive education in Uzbekistan, the strategic goals of the inclusive education system are:

- General Education in the integrated (inclusive education) of children with disabilities in the system of intentional (inclusive education) education, creating equal opportunities for the development of best international experience and modern modern requirements;

- Education "On Education", Inclusive Education to Educate Esspression, "On Education of Persons with Disabilities", forming the positive attitude of health care, people with disabilities to ensure the integration of the health environment approval of substances on;

- Regulation of the legal framework, improving regulatory security issues in accordance with the purposes and priorities of education policy purposes;

- Sustain development of inclusive education, rehabilitation of children with disabilities, rehabilitation of children with disabilities as strategic resource for children with disabilities, adaptation and integration;

- All of strategic structures, government and nongovernmental organizations in order to develop inclusive education;

- The Popularity of Inclusive Education, ensuring the level of development, taking into account the 
The American Journal of Political Science Law and Criminology

(ISSN - 2693-0803)

VOLUME 04 ISSUE 01 Pages: 52-56

SJIF IMPACT FACTOR (2020: 5. 453) (2021: 5. 952)

OCLC - 1176274523 METADATA IF - 7.659

educational needs of the educational system, covers the characteristics;

- Creation of mechanisms in general education and mutual agreement to ensure integration of children with disabilities in the secondary environment;

- Development of special curricula for inclusive educational institutions, educational and methodical complexes;

- The formation of those around Tavar, forming communication with other peers, in students and communication and tolerance;

The need to the need for the development of inclusive education listed above is crucial in the effective organization of education of persons with disabilities. According to the Law of the Republic of Uzbekistan "On the Rights of Persons with Disabilities, people with disabilities have the right to study throughout the educational organizations and to participate in the life of society and the state for the entire life. Guarantees the necessary conditions for the development of inclusive education, their education, and retraining and retraining and retraining, and training of professional training. [4] Educational organizations jointly provide children with disabilities to preschool, extraplaced and general secondary education, as well as after secondary special, professional, higher and higher education.

It is also determined in accordance with the Constitution of the Republic of Uzbekistan that it is eligible to free knowledge. [5] Today in 86 specialized schools and boarding schools for children in physical or mental development in physical development (followup - specialized educational institutions) for the total 86 specialized school and boarding schools - 3,100 students in school boarding schools - get brought up. Also, 13.3 thousand students in need of treatment are taught at home individually. In 2014-2016, in cooperation with the European Union, the project "Inclusive Education for Children with a separate education in Uzbekistan" was implemented. As part of the project:

- Experimental fields have been organized in 5 regions of the country;

- More than 150 medical-pedagogical commissions and more than 1.3 thousand educators were trained in inclusive education services;

- Curricula for training institutions for retraining and advanced training of educational institutions have been introduced into 3 training modules for the education system;

- Inclusive education services were established to children and their parents with specialized education needs;

In Tashkent, Samarkand, Namangan, Khorezm and Surkhandarya regions, 5 experimental schools and 15 experimental schools were established and more than 800 children were covered. A number of normative legal acts on the introduction of inclusive education has been adopted. These documents have identified measures aimed at social supporting children in need of our society, educating them, their ability to provide them with healthy children, and spiritual development. In particular, further improving the efficiency of measures to provide social guarantees for the PC-3931 of September 5, 2018, in the Resolution of the Public Education system, their education ( It has been recorded on the creation of a complexity environment for the creation of an environment of adaptation that serves to obtain inclusive education). Also, a decree of the President of the Republic of Uzbekistan No. PF-5712 of the Republic of Uzbekistan dated April 29, 2019, A number of conceptual significant interest has been done to improve the quality of educational services 
The American Journal of Political Science Law and Criminology

(ISSN - 2693-0803)

VOLUME 04 ISSUE 01 Pages: 52-56

SJIF IMPACT FACTOR (2020: 5. 453) (2021: 5. 952)

OCLC - 1176274523 METADATA IF - 7.659

provided to children with special educational services in the Concept of the Republic of Uzbekistan. In particular, the concept of state for strategic goals has been developed. We think this concept for developed plays a major role in the effective organization of inclusive education management. The concept is made in two stages, including:

A) During the 2020-2022:

- Normative base will be improved in the field of inclusive education system;

- Qualified teachers for inclusive education system are trained, retrained, retrained, and their skills will be made;

- The material and technique of institutions is strengthened, they are provided with special devices (lifting device, panboard, handle, etc.), necessary literature, manuals, equipment and equipment for various professions;

- The Inclusive Education will introduce modern information and communication technologies and innovative projects;

- The right of children with separate needs, a positive social environment is formed among the population by explaining the content of inclusive teaching;

- There is measures to prevent the discrimination of children with separate needs, prevent negative circulation;

- The Inclusive Education System shall be introduced into the activities of special educational institutions as an experimental history;

B) During the year 2023 - 2025:

- The system of inclusive education is gradually introduced in other general secondary education institutions;
- There is measures to ensure the right of each child with separate needs of education is carried out;

- Training methods are improved, and the principles of individualization will be gradually introduced into the educational process;

- The test process takes measures to spiritual and moral upbringing students, the formation of physical and energetic and energetic and energetic and energetic and energetic and energetic and energetic and energetic and enforce children in the Inclusive Education Preparations;

The number of public education institutions (schools and boarding schools) (hereinafter - specialized educational institutions) (hereinafter - specialized educational institutions) is optimized for children with special educational institutions from the physical and mental needs of students and the geographical location of educational institutions. Resolution of the President of the Republic of Uzbekistan. On measures to further improve the system of education for children with special educational needs 13.10.2020 [6]

Based on the above points and feedback, it will be appropriate to mention the following conclusions. As in Uzbekistan, in connection with inclusive education, the renewal of the legal framework in the field is becoming a life needy. In particular, it is advisable to develop a special sectoral legislation on inclusive education. The effective operation of the nichesis of involving young people in inclusive education in terms of disability is serving the main factor in this area.

\section{REFERENCES}

1. A application for the people of Uzbekistan on December 3 - on the occasion of the International Day of Persons - [03.12.2021]

2. Law of the Republic of Uzbekistan. About ratification of the Convention on the Rights of 
The American Journal of Political Science Law and Criminology

(ISSN - 2693-0803)

VOLUME 04 ISSUE 01 Pages: 52-56

SJIF IMPACT FACTOR (2020: 5. 453) (2021: 5. 952)

OCLC -1176274523 METADATA IF -7.659

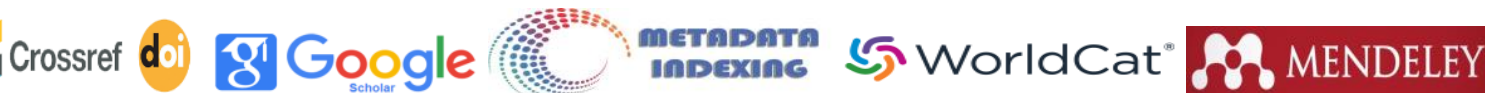

Publisher: The USA Journals

Persons with Disabilities (New York,

13.12.2006) [07.06.2021]

3. Law of the Republic of Uzbekistan About

Education [23.09.2020 20-m]

4. On the rights of persons with disabilities of the

Republic of Uzbekistan [15.10.2020 38-m]

5. Constitution of the Republic of Uzbekistan [41-

m.]

6. Resolution of the President of the Republic of Uzbekistan. On measures to further improve the system of education of children with special education [13.10.2020] 